\title{
Significance of Extra-Hepatic Metabolism of Xenobiotics
}

\author{
A M Homeida*, Aziza T F El Khaldi \\ Department of Biology, College of Science and Basic and Applied Scientific Research Center, Dammam, Imam Abdulrahman Bin Faisal \\ University, Saudi Arabia \\ *Corresponding author's: A M Homeida, Department of Biology, College of Science and Basic and Applied Scientific Research \\ Center, Dammam, Imam Abdulrahman Bin Faisal University, Saudi Arabia
}

\section{ARTICLE INFO}

Received: 㹸 July 30, 2019

Published: 幽 August 08, 2019

Citation: A M Homeida, Aziza T F El Khaldi. Significance of Extra-Hepatic Metabolism of Xenobiotics. Biomed J Sci \& Tech Res 20(3)-2019. BJSTR. MS.ID.003445.

\begin{abstract}
The contribution of extra-hepatic xenobiotic enzyme activity was determined in sheep and rat. Some of extra-hepatic tissues (Placenta) may have enzyme system that are equal to or a little lower than the corresponding activities in the liver. It is suggested that the extra-hepatic contribution to enzyme activity should be considered when drug disposition is determined.
\end{abstract}

Keywords: H: Xenobiotic Metabolizing Enzymes; Extra-Hepatic Tissue; Animals

\section{Introduction}

Most absorbed xenobiotics undergo biotransformation in the body by phase- 1 reaction, by introducing a functional group $(-\mathrm{OH}$ $\left.-\mathrm{NH}_{2},-\mathrm{SH}\right)$, that converts the compound into a polar metabolite readily to be excreted. If not, then the compound undergoes a subsequent phase-11 reaction in which an endogenous substrate combines with newly functional group to form highly polar conjugate. These events occur mainly in the liver and in extrahepatic tissue. Considerable attention has been paid to the role of environmental xenobiotics in the etiology of many diseases in man and animals. Xenobiotics entering tissues must be very lipophilic to be able to cross the cell membrane lipoid barriers to enter the cells. It is thus conceivable that metabolism in blood vessels as well as adjacent tissue would greatly affect pharmacokinetics elicited by xenobiotics. The importance of extra-hepatic metabolism of xenobiotic stems from the fact that tissue distribution of xenobiotic enzymes relates to target organs selectivity of xenobiotic. A larger proportion of xenobiotics exhibit marked tissue specificity. For example, carcinogenic compounds may produce cancer at sites and not others. A local circulation in the body may deliver a drug or hormone to a target organ but, no other tissues. The importance of extra-hepatic tissue in the metabolism of xenobiotics is illustrated by determination of expression of phase- 1 and phase- 11 xenobiotic metabolizing enzymes.

In this review evidence is also gathered to demonstrate the ability of extra-hepatic tissues to effectively contribute to the production of xenobiotic metabolizing enzyme activity. Enzymes activity were determined by spectrophotometric methods previously described and validated. Table 1 summarizes the activity of varies metabolizing enzymes in liver and extra-hepatic tissues. Some of extra-hepatic tissues (Placenta) may have xenobiotic metabolizing enzyme system that are equal to or a little lower than the corresponding activities in the liver. This is useful in case of liver dysfunction or anhepatic conditions. It is expected that the extra-hepatic metabolism may contribute to elimination of drugs. Therefore, this contribution should be taken into consideration when drug disposition is determined [1-5]. 
Table 1: Mean activity of drug metabolizing enzymes (nmole/mg microsomal protein/min) in tissues of sheep and rat.

\begin{tabular}{|c|c|c|c|c|}
\hline Enzyme Activity & Liver Sheep/Rat & Kidney Sheep/Rat & Duodenum Sheep/Rat & Placenta Sheep \\
\hline \multicolumn{5}{|c|}{ Phase-1 Enzymes } \\
\hline $\begin{array}{c}\text { Amino pyrine-N- } \\
\text { demethylase }\end{array}$ & $6.2 / 8.7$ & $0.82 / 1.2$ & $1.8 / 2.4$ & 0.51 \\
\hline Aniline-4- hydroxylase & $0.61 / 0.33$ & $0.21 / 0.23$ & $0.26 / 0.18$ & 0.41 \\
\hline $\begin{array}{c}\text { Ethoxycoumarin-0- } \\
\text { deethylase }\end{array}$ & $0.72 / 0.51$ & $0.02 / 0.01$ & $0.02 / 0.01$ & 0.81 \\
\hline \multicolumn{5}{|c|}{ Phase-2 Enzymes } \\
\hline UDP-glucuronyl transferase & $1.3 / 1.1$ & $0.41 / 0.39$ & $0.50 / 0.78$ & 0.7 \\
\hline Glutathione-S-transferase & $200 / 170$ & $48.3 / 41.6$ & $68.1 / 48.6$ & 83.3 \\
\hline
\end{tabular}

\section{Conclusion}

a) Evidence is gathered to demonstrate the ability of extrahepatic tissues to effectively contribute to the production of xenobiotic metabolizing enzyme activity

b) Some of extra-hepatic tissues (Placenta) may have enzyme system that are equal to or a little lower than the corresponding activities in the liver.

\section{References}

1. Pettonen O, Raunio H (1997) Metabolic activities of toxins: Tissuespcific expression and metabolism in target organs. Environmental health Perspective 105(4): 767-774.

ISSN: 2574-1241

DOI: $10.26717 /$ BJSTR.2019.20.003445

A M Homeida. Biomed J Sci \& Tech Res

CC (P) This work is licensed under Creative

Submission Link: https://biomedres.us/submit-manuscript.php
2. Homeida AM, Al-Eknah, MM, Dafalla EA (1993) Drug-metabolizing enzymes in placenta and foetus of camel and sheep. Reprod.Dom.Anim 28: 258-262.

3. El Sheikh HA, Ali BH, Homeida AM, Hassan T, Hapke, HJ, et al. (1988) The activities of amino-n-demethylase, aniline 4-hydroxylase and UDPGlucuronyl transferase in tissues of camels, desert sheep and Nubian goats. Gen. Pharmacol 19(5): 713-717.

4. El Sheikh HA, Ali BH, Homeida AM, Hapke HJ (1991) Activities of glutathione-s-transferase and ethoxycoumarin-o-deethylase in tissues of camels, sheep, goats and rats. Comp. Biochem.Physiol.C: Comp Pharmacol 98(2-3): 293-297.

5. Hassan A, Fontana RJ (2019) The diagnosis and management of idiosyncratic drug induced liver injury. Liver Int 39(1): 31-33.

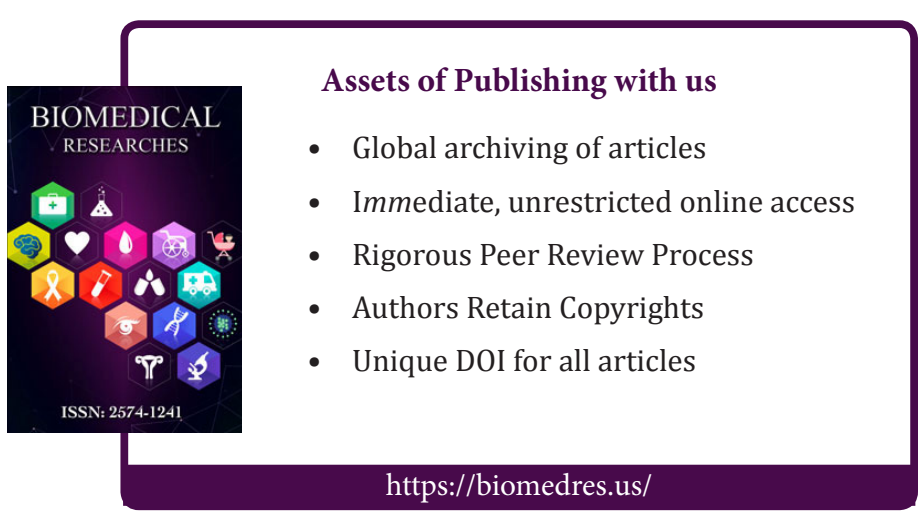

